\title{
Den journalistiske dækning af toppolitikere på turne ${ }^{1}$
}

\section{AF KRISTIAN SERGE SKOV-LARSEN}

Denne artikel undersøger effekten af Mogens Lykketoft og Anders Fogh Rasmussens turneer i valgkampen i 2005. Formålet med turneerne var at bruge de lokale medier til nemmere og mere uspoleret at komme igennem med partiets politik og samtidig eksponere de to statsministerkandidater.

Artiklens konklusion er, at de lokale mediers adfærd ikke svarer til de forventninger, som partierne har inden turneerne. Mediernes dækning af turneerne er mindre end forventet, mere kritisk og med markant mindre fokus på politik end på proces og personer.

Det betyder, at de centrale partiorganisationer nok bør se sig om efter andre måder at påvirke de lokale medier, end blot ved at sende toppolitikerne på turne.

Da Anders Fogh Rasmussen en uge inde i valgkampen i 2005 steg ind i en af sine store blå busser for at begive sig ud i landet, var han tilsyneladende på vej ud for at gentage et af de mest effektive tiltag fra folketingsvalgkampen i 2001: En to-ugers turne, som ikke handlede om, at christiansborgjournalisterne skulle skrive om partilederen på farten, men som udelukkende havde til formål at nå direkte igennem til så mange lokale medier som overhovedet muligt. Efter valgkampen i 2001 blev netop den landsdækkende busturne fremhævet som et meget stærkt strategisk træk, som Anders Fogh Rasmussen og Venstre havde gennemført (Jønsson, 2002: 105), og i 2005 sprang endnu flere partier der- 
for med på turnebussen og lavede deres egen lokale tour-karavaner.

De journalistiske nyhedskriterier bliver som regel regnet for at være den gode historie sat på formel. Nyhedsopskriften siger, at den gode nyhed både er aktuel, væsentlig, sensationel, har konflikt og rummer en umiddelbar identifikation hos læserne. Er der mindre af det ene, skal der være mere af det andet. (Kramhøft, 2001: 52)

Man skal kun have læst nyhedskriterierne en enkelt gang for at kunne gennemskue, at det selvfølgelig er en større nyhed for Skive Folkeblad, når statsministeren holder tale på den lokale folkeskole, end når han holder en på Christiansborg. Men man behøver også kun at have studeret avisernes oplagstal en enkelt gang for at gennemskue, at det selvfølgelig er mere interessant at komme i Politiken frem for Purhus-Tjele Ugeavis.

Når Venstre alligevel tilrettelagde en turne i 2001 med det direkte formål at komme i de lokale medier, var det fordi partiets strateger antog, at der her var nogle hidtil uhøstede fordele at hente, som ville opveje de langt mindre oplagstal hos de lokale medier.

Men giver partiledernes lokale valgkampsturneer i 2005 virkelig den medieomtale og den nemme adgang til de lokale medier, som partierne forventer? Det vil jeg undersøge i denne artikel. Artiklen bygger på en undersøgelse lavet i forbindelse med den afsluttende opgave på første del af den journalistiske kandidatgrad, cand. public. på SDU. Selve opgaven, som indeholder en lang række uddybende metodeforklaringer og mere indgående analyser af de enkelte medier samt selve datasættet, er at finde på hjemmesiden www.serge.dk.

Men inden de lokale medier kommer under lup, vil jeg redegøre for, hvad partierne selv forventede at få ud af at sende deres partiledere på turne.

\section{Hvad forventede partierne?}

Min opstilling af partiernes forventninger bygger på interviews, foretaget af Rasmus Jønsson, med ledende kampagneansvarlige i Venstre og Socialdemokratiet. Disse interviews er foretaget i for- 
bindelse med en evaluering af valget i 2001 (Jønsson, 2002), og inden valget i 2005 blev skudt i gang (Jønsson, 2004).

Disse interviews med partiernes kampagneansvarlige viser, at kampagnelederne opstiller en række hypoteser om, at de lokale mediers dækning vil være mere favorabel for partilederne, og hvordan den nærmere vil være det. Kampagneledernes forventninger bliver formuleret forskelligt i de brugte interviews. Jeg har valgt at sammendrage og opstille forventningerne på følgende måde:

Kampagnelederne forventer at:

1. Det er langt lettere for politikerne at komme i de lokale og regionale medier end i de landsdækkende i en folketingsvalgkamp.

2. De lokale og regionale journalister behandler politik anderledes end de landsdækkende medier. De vinkler ikke lige så kritisk som disse, og de har mindre fokus på politik end på proces. Derfor forventer de to partier at få deres budskaber mere uspoleret ud til vælgerne.

3. Det er muligt at få en-kildes historier eller solointerviews i de lokale medier ved at invitere journalisterne til at interviewe partilederen i bussen.

4. De lokale journalister er den rigtige måde at nå de lokale medier på i en valgkamp.

5. De når målgrupper igennem de lokale og regionale medier, som ikke bliver eksponeret for den politiske dagsorden i de landsdækkende medier, og de kan differentiere deres budskaber bedre efter lokale forhold.

Selvfølgelig kan partiledernes turneer også handle om direkte kampagneaktivitet, fx om at få partilederne til at trykke så mange hænder som muligt, men da målet for denne artikel er at belyse medieeffekten af turneerne, vil det ikke blive behandlet yderligere.

Hypotese nr. 4 bliver ikke direkte udtrykt eller diskuteret i nogle af de interviews, jeg har behandlet, men den er en formulering af noget, som de kampagneansvarlige anser for at være en selvfølge. Men det er det langt fra, som jeg vil vise i det følgende. 
Rigtigheden af hypotese nr. 5 skal ikke undersøges i denne artikel, men det kan gøres af partierne og andre ved hjælp af f.eks. Index Gallup og mediebureauer, som kan give en meget omfattende oversigt over medieforbruget hos forskellige udsnit af danskere.

At undersøge, i hvor stort omfang de lokale læsere også bliver eksponeret for de landsdækkende medier er en opgave for sig. I denne artikel vil jeg gemme den nærmere analyse til en anden gang og nøjes med at gå ud fra, at der er fordele ved at opnå eksponering i de lokale medier.

Det er altså de fire første hypoteser, jeg vil give en mere indgående behandling i denne artikel.

For at teste hypoteserne hos partierne har jeg undersøgt mediebilledet i to udvalgte områder, Viborg amt og Odense, i en uge omkring Anders Fogh Rasmussen og Mogens Lykketofts besøg i valgkampen.

\section{Tabel 1}

Oversigt over turneer i valgkamp 2005 af Mogens Lykketoft og Anders Fogh Rasmussen.

\begin{tabular}{lcc}
\hline & Anders Fogh Rasmussen & Mogens Lykketoft \\
\hline Antal dage & 10 & 8 \\
\hline Antal amter & 12 & 9 \\
\hline Antal byer & 28 & 15 \\
\hline Antal besøg & 46 & 27 \\
\hline
\end{tabular}

De to partiledere, Anders Fogh Rasmussen og Mogens Lykketoft, er valgt som artiklens fokus, fordi de satte ud på de mest omfattende turneer i valgkampen (se tabel 1). Jeg har analyseret medierne i ugen omkring deres besøg med hensyn til den øvrige valgdækning i de lokale medier, idet jeg håber på den måde at kunne sige noget om den kontekst eller baggrundsstøj, som dækningen af deres besøg skal ses i.

De to områder er udvalgt dels fordi begge partiledere besøger dem inden for samme uge, dels fordi de tilsammen har et meget varieret medieudbud i form af dagblade, gratisaviser, regionale 
TV-stationer og ugeaviser. Ingen af stederne er heller skueplads for landspolitiske begivenheder, som kunne gøre det svært at skelne imellem medieomtale af lokale turneer eller medieomtale af lokale begivenheder, som havde relevans for den nationale valgkamp.

Radiostationernes dækning er desværre fravalgt i denne undersøgelse, da Statens Mediearkiv kun i begrænset og vanskeligt tilgængeligt omfang gemmer radioudsendelser.

\section{Giver turneerne en synlig medieeffekt?}

Partiernes antagelse er, som beskrevet ovenfor, at det er langt lettere for politikerne at komme $i$ de lokale og regionale medier end $i$ de landsdcekkende i en valgkamp. Denne antagelse ligger i forlængelse af nyhedskriterierne, som jo også dikterer, at det i en eller anden grad er en nyhed, når en statsministerkandidat kommer på besøg.

I tabel 2 ses en opgørelse over det samlede antal artikler og tvindslag bragt af de undersøgte medier om folketingsvalgkamp i almindelighed og om partiledernes turne i særdeleshed.

Den sidste kolonne „Artikler om Svendborg“ viser, hvor mange af artiklerne og tv-indslagene om turneen, der handler om statsministerens besøg i Svendborg, hvor han blev mødt af en meget aggressiv autonom moddemonstration, som forvandlede dette lokale besøg til en landspolitisk nyhed (Bro et al, 2005: 23).

For at konkludere, om turneen giver en synlig medieeffekt, er det nødvendigt at dele de 22 undersøgte medier op i nogle mindre grupper.

\section{Ugeaviser/distriktsblade}

I de 15 ugeaviser i undersøgelsen (angivet med *** i tabel 2), også kendt som distriktsblade, var der, som det fremgår af tabel 2, ikke den store valgkampsdækning.

Min undersøgelse omfatter to udgivelser af hver avis.

Søndagsavisen distrikt 11 laver deres artikler om valgkamp centralt i København.

Fraregner man disse, er der færre end én artikel om valgkamp pr. avis i perioden. Til sammenligning har partierne indrykket i 


\section{Tabel 2}

Antal artikler/indslag om valgkampen.

\begin{tabular}{|c|c|c|c|}
\hline & $\begin{array}{c}\text { Alle } \\
\text { Artikler }\end{array}$ & $\begin{array}{c}\text { Artikler om } \\
\text { turneen }\end{array}$ & $\begin{array}{l}\text { Artikler om } \\
\text { Svendborg }\end{array}$ \\
\hline Fyens Stiftstidende * & 110 & 9 & 3 \\
\hline Urban Fyn ** & 82 & 3 & 2 \\
\hline Skive Folkeblad * & 42 & 3 & 0 \\
\hline Viborg Stifts Folkeblad * & 69 & 11 & 3 \\
\hline Xtra (kun lokal) ** & 11 & 2 & 2 \\
\hline Ugeavisen Karup *** & 6 & 0 & 0 \\
\hline Viborg Bladet *** & 0 & 0 & 0 \\
\hline Midt på ugen Skive *** & 1 & 0 & 0 \\
\hline Viborg Nyt *** & 0 & 0 & 0 \\
\hline Vesthimmerlands avis $* *$ & 5 & 2 & 0 \\
\hline Thylands Avis *** & 4 & 0 & 0 \\
\hline Ugeavisen Odense $* * *$ & 3 & 2 & 0 \\
\hline Søndagsavisen Distrikt $11 * * *$ & 7 & 0 & 0 \\
\hline Lokalavisen Odense $* * *$ & 1 & 0 & 0 \\
\hline Thistedposten $* * *$ & 3 & 0 & 0 \\
\hline Spøttrup Ugeavis *** & 0 & 0 & 0 \\
\hline Purhus Tjele ugeavis *** & 3 & 1 & 0 \\
\hline Kjellerup tidende $* * *$ & 0 & 0 & 0 \\
\hline Fjends Herreds folkeblad $* * *$ & 0 & 0 & 0 \\
\hline Bjerringbro tidende $* * *$ & 1 & 0 & 0 \\
\hline TV 2 Midtvest *** & 32 & 3 & 0 \\
\hline TV 2 Fyn & 30 & 4 & 3 \\
\hline
\end{tabular}

*Dagblade ** Gratisaviser *** Ugeaviser/distriktsblade

alt 270 annoncer i samme periode i aviserne, der er altså gennemsnitligt ca. 10 annoncer for hver redaktionel artikel om valgkamp.

Hele dækningen af partiledernes turne i de gratis ugeaviser refererer til to stop på turneen. Det ene i Odense, det andet i Klejtrup. Til sammenligning stopper partilederne i syv forskellige 
byer inden for undersøgelsesområdet med i gennemsnit et par aktiviteter ved hvert stop i den periode, der undersøges.

Man kan selvfølgelig ikke tillade sig bare at addere dette antal op i forhold til hele turneen, men hvis man for et øjeblik alligevel gør dette for sammenligningens skyld, ville det svare til at partiledernes i alt 73 besøg ville blive dækket i omkring 20 gratis ugeaviser på landsplan.

Til sammenligning er der omkring 300 gratis ugeaviser på landsplan (Andersen, 2005: 141).

\section{Gratisaviserne}

Åbner man de nye gratisaviser (angivet med ** i tabel 2) under en valgkamp, skal man ikke forvente at finde omtale af partiledernes turneer rundt i landet.

De to gratisaviser, jeg har undersøgt, har i alt kun 5 omtaler af partiledernes turne, hvoraf de 4 refererer til Anders Foghs sammenstød med de autonome i Svendborg. Den sidste „artikel“, som er et billede fra Scanpix og et par liniers tekst (Bagger, 2005), handler om Mogens Lykketofts besøg hos Arla Foods i Holstebro, hvor han skulle have hvid kittel og en lille sjov hvid hat på.

Gratisaviserne interesserer sig altså overhovedet ikke for partiledernes turne, og turneen har næsten ikke nogen synlig effekt i den uge, jeg har undersøgt.

\section{De regionale TV 2-stationer}

Begge de to regionale TV 2-stationer dækker partiledernes turne. Det ser ud til, at hver partileder får et enkelt indslag i på hver station, uanset hvor omfattende i dage og besøg partiledernes turne er i regionen. Dog er indslaget med Mogens Lykketoft i TV 2 Midtvest udformet, så man ser besøget ud fra synsvinklen hos en lokal socialdemokrat, som så efterfølgende interviewes i studiet (derfor tæller indslaget for to enheder). Lykketoft er overhovedet ikke i fokus, selvom turneen nævnes og bruges som afsæt.

Indslagene med Anders Fogh Rasmussen i TV 2 Fyn handler udelukkende om angrebet i Svendborg og har intet politisk indhold, og den efterfølgende dækning i dagene efter handler primært om det autonome miljø i Svendborg, selvom turneen nævnes, og indslagene derfor optræder i datamaterialet. 
De to andre indslag, Lykketoft i TV 2 Fyn og Anders Fogh Rasmussen i TV 2 Midtvest, er reportager fra partiledernes besøg. Indslagene er vinklet efter opskriften „en partileder kommer til byen“ og har både reportager fra besøgene og politiske statements fra kandiddaterne, og tager begge et par minutter hver. Ikke noget klokkeklart politisk fokus, men især igennem soundbytes fra debatter, bliver kandidaternes politik alligevel gjort klart.

En klokkeklar konklusion på disse fund ville kræve et gennemsyn af alle regioners tv-udsendelser, men der er dog meget som tyder på, at partilederne får et indslag i hver regional TV 2-station, når deres turne er i området - uanset varigheden af besøgene i området. Med mindre der altså sker noget ekstraordinært, således som der gjorde i Svendborg.

\section{Dagbladene}

Dagbladene (angivet med $*$ i tabel 2) har generelt lille interesse i turneen, men den er dog større end interessen hos de gratis ugeaviser og gratisaviserne.

Når partilederne besøger byerne, stiller dagbladene som regel op og dækker besøget på den ene eller anden måde. De tre aviser har, hvis man ser bort fra forsidehenvisninger og artikler om de autonome i Svendborg, 14 artikler om de to partilederes besøg til sammen. Disse artikler skal holdes op imod de 221 artikler om valgkamp, som aviserne ellers bringer i samme periode.

2,5 artikel i snit pr. dagblad pr. partileder lyder måske ikke så imponerende, men sammenholder man dagbladenes dækning med de andre medier i undersøgelsen, er det klart den mest omfattende dækning.

\section{Vinkler de lokale journalister anderledes?}

En anden hypotese hos partierne er, at de lokale og regionale journalister behandler politik anderledes end de landsdoekkende medier. De vinkler ikke lige så kritisk som disse, og de to partier kan derfor få deres budskaber mere uspoleret ud til valgerne.

Denne antagelse er lidt sværere at behandle end den rent kvantitative medieeffekt af turneen, men det er muligt at nå frem til en 
vis vurdering af de lokale mediers kritiske sans overfor partilederne. En vurdering, hvis grundlag dog kan forbedres gennem yderligere undersøgelser.

For at kunne sige noget om de lokale dagblade og gratisavisers kritiske dækning må man kunne sammenligne med de landsdækkende mediers dækning.

I denne artikel bruger jeg de resultater, som undersøgelsen „Mediernes valgkamp“ (Bro et al, 2005) nåede frem til. Når jeg refererer til „landsdækkende artikler“, drejer det sig altså om et uddrag af denne undersøgelses datasæt om de landsdækkende medier, tilpasset den relevante undersøgelsesperiode.

\section{Har de lokale mere fokus på proces?}

Som det ses i tabel 3 adskiller de lokale dagblades, TV 2-stationernes og gratisavisers dækning af proces, personer og politik sig ikke fra den landsdækkende dækning.

Cirka halvdelen af de lokale dagblades artikler er lavet af et pressebureau, typisk Ritzaus Bureau, men selv hvis man frasorterer disse artikler og alene undersøger de lokalt producerede enheder, adskiller de lokale medier sig ikke fra de landsdækkende i henseende til vægtning i fokus på proces, personer og politik.

Kun det lokale bureaustofs lidt større fokus på politisk indhold frem for proces, og de lokalt producerede artikler og tv-indslags fokus på personer frem for politik, skiller sig ud.

Når de lokalt producerede medier har lidt større fokus på personer frem for politik, kan det skyldes, at flere medier bruger en del tid og plads på at interviewe og portrættere lokale kandidater.

\section{Tabel 3}

Dækker pressen anderledes? Procent

\begin{tabular}{lcccc}
\hline & Proces & Personer & Politik & I alt \\
\hline Alle lokale artikler (315) & 41 & 21 & 38 & 100 \\
\hline Lokalt producerede artikler (149) & 44 & 24 & 32 & 100 \\
\hline Lokalt Bureaustof (162) & 39 & 19 & 42 & 100 \\
\hline Regionale TV 2-stationer (63) & 43 & 24 & 33 & 100 \\
\hline Landsdækkende aviser (1287) & 44 & 19 & 37 & 100 \\
\hline
\end{tabular}


Forskellen kan også skyldes, at de fleste nye politiske tiltag udgår fra Christiansborg, og dermed kommer i de lokale medier via bureaustoffet, mens de lokale kandidater mest kommer i medierne i artikler, der har fokus på deres personlige kandidatur. Forskellen i fokus kan også være udtryk for en anderledes prioritering hos Ritzau - en antagelse, hvis rigtighed kræver en undersøgelse for sig.

Ser man samlet på alle lokale artikler, udligner forskellene sig, idet der kun er to procentpoints forskel mellem proces og personer, når man sætter alle de lokale artikler overfor de landsdækkende. Forskellen mellem henholdsvis de nationale og lokale mediers behandling af politik og valgkamp må altså siges at være meget lille, og de politiske budskaber er ikke i højere grad i centrum lokalt, sådan som kampagneplanlæggerne håbede.

\section{Vælger de lokale journalister andre emner?}

Man kan se, om den lokale politiske dagsorden adskiller sig fra den nationale, ved at sammenligne resultaterne fra undersøgelsen „mediernes valgkamp“ med resultaterne fra min egen undersøgelse.

Udlændinge-spørgsmålet var det vigtigste emne både lokalt og nationalt. Udover det er de fundne forskelle små: Emner som ældre, uddannelse og forskning, etik og moral og international politik er lidt bedre repræsenteret i den landsdækkende presse end i den lokale, mens folkeskolen, skatter og afgifter og velfærd i øvrigt synes at være lidt overrepræsenteret i den lokale presse.

Det vigtigste resultat i denne sammenligning af valgkampsemner er, at der hverken i de landsdækkende eller de lokale medier er et fælles emne for valgkampen. Intet emne er hovedtema i mere end 5 procent af artiklerne - heller ikke udlændige. I valgkampen i 2001 (Bro et al, 2005: 12) var udlændingepolitik klart overordnet tema. Men selvom udlændinge også er topscorer denne gang, er det langt fra så markant. Et fælles tema er altså fuldstændig fraværende i 2005. Det vigtigste tema både lokalt og nationalt er valgkampen selv, altså proces og personer. 


\section{En-kildes historier}

En anden måde, hvorpå man kan undersøge, om de lokale journalister vinkler anderledes og mindre kritisk, er ved at se på partiernes antagelse nr. 3: Det er muligt at få en-kildes historier eller solointerviews i de lokale medier ved at invitere journalisterne til at interviewe partilederen $i$ bussen.

Hvis denne antagelse er rigtig, er det et klart tegn på, at partilederne får en mindre kritisk behandling hos lokaljournalisterne. Undersøgelsen af denne antagelse kan derfor bruges som afsæt til en vurdering af, hvordan journalisterne behandler turneerne.

Undersøger man de lokale dagblades dækning af selve turneen og sorterer forsidehenvisninger, artikler om besøget i Svendborg og notitser på mindre end fem linjer fra, er der i alt 14 regulære artikler tilbage, som omhandler partiledernes turne.

En nærmere undersøgelse af disse 14 artikler afslører, at det kun er en enkelt dagbladsjournalist, som har taget imod tilbuddet om at interviewe partilederne, nemlig Jesper Markussen på Viborg Stifts Folkeblad, som både har interviewet Anders Fogh Rasmussen (Markussen, 2005a) og Mogens Lykketoft (Markussen, 2005 b). Hovedtemaet i begge artikler er politik. Kommunalreformen er emne for den ene, arbejdsmarkedet for den anden.

Jakob Moll fra Fyens Stifttidende har også perifert interviewet Mogens Lykketoft til sidst i artiklen „På bagsædet af Linje A“ (Moll, 2005), men det interview er for det første en meget lille del til sidst i en større reportage, for det andet handler interviewet kun om, hvorvidt Lykketoft er træt af at turnere rundt, når han alligevel er bagud i meningsmålingerne. I de resterende 11 dagbladsartikler dækker journalisterne kun det faktum, at partilederne er på besøg. De har ikke interviewet kandidaterne, og den politik, der bliver formidlet, er de spørgsmål og svar, som bliver givet i forbindelse med debatmøderne. Vinkel og emne for journalisternes artikler synes derfor i høj grad at ligge uden for politikernes kontrol.

Tabel 4 er konstrueret ved en optælling af, hvor mange spaltemillimeter journalisterne bruger på hhv. proces og politik, og den viser, at deres reportager består ligeligt af begge dele. Sammenholder man dette med den kendsgerning, at de kun er reportager 


\section{Tabel 4}

Sådan dækkes debatmøder. Procent

\begin{tabular}{lcc}
\hline & Proces & Politik \\
\hline Artikler om debatmøder & 51 & 49 \\
\hline
\end{tabular}

fra debatmøder, må konklusionen blive, at de lokale dagblades dækning ikke er så nem at påvirke og plante politiske budskaber i, som politikerne håbede.

En enkelt journalist fra Odense Ugeavis har også taget imod tilbuddet om at interviewe de to partiledere i bussen. Han har derefter lavet et opslag på side 34-35 i avisen med en partileder på hver side. En journalist fra TV-Midtvest er også blevet lokket op i Foghs bus.

Ser man på helhedsbilledet af turneen, er det imidlertid klart, at partiernes målsætning langt fra opfyldes, når kun tre journalister vælger at tage imod tilbuddet og interviewer partilederen. Flere journalister kan selvfølgelig have været på besøg i tour-bussen - men de har i så fald ikke brugt det i deres journalistiske produkt.

\section{Hvordan dækker resten?}

Jeg har allerede været inde på, om især dagbladene dækker turneen og valgkampen mindre kritisk end den landsdækkende presse. Men da mine andre medier har en langt mindre dækning og derfor er i fare for at drukne i en sådan overordnet analyse, kunne det være relevant at lave en selvstændig analyse af disse for at se, om partilederne i disse medier har mulighed for at opnå et resultat.

\section{De regionale TV 2-stationer dækker ligeligt}

Jeg har undersøgt nyhedsudsendelserne kl. 19.30 på TV 2 Fyn og TV 2 Midtvest, som i de undersøgte 8 dage sender i alt 7 timers regionale programmer, hvoraf over 4 timer handler om folketingsvalgkampen. Derudover kommer lange formiddags - og dagsmagasiner med kandidatdebatter. 
Denne i tid massive valgdækning, skyldes især lange studiedebatter med repræsentanter for de forskellige partier og særlige valgkampsmagasiner på begge stationer. Selvom jeg ikke har undersøgt det nærmere, har jeg indtryk af, at disse debatter og indslag med megen omhu er tilrettelagt, så alle kandidater og partier bliver tilgodeset. Som tidligere nævnt udløser partiledernes turneer også et ligeligt fordelt antal indslag i disse medier.

På Fyn drukner Anders Foghs besøg fuldstændig i de autonomes overfald, men når man kigger på de lokale TV 2-stationers øvrige praksis, må det formodes, at hans besøg havde fået en eller anden form for dækning under alle omstændigheder, også selvom de autonome ikke var dukket op. Hvis man ikke medregner indslag, hvor turneen bare bliver nævnt perifert, virker det, som om kandidaterne får præcist et indslag og ikke mere pr. TV 2region.

Selvom de lokale TV 2-regioners vinkling ifølge forventningen skulle være mindre kritisk end de landsdækkende mediers, er dækningen den samme over for alle kandidater, ligegyldigt hvor omfattende turneen er i TV-stationens landsdel.

\section{Gratisaviserne dækker næsten ikke}

Som jeg allerede har nævnt dækker gratisaviserne stort set ikke partiledernes turne. Men faktisk dækker gratisaviserne stort set heller ikke den lokale valgkamp, selvom de hedder Urban Fyn og Xtra Fyens Stiftstidende og derfor burde have lokal tilknytning. Urban Fyn og Xtra har godt nok 11 lokalt producerede enheder i alt om valgkamp i den undersøgte uge, men artiklerne handler enten om befolkningens valgtræthed, om lokale anderledes valghappenings, eller de er rene fotos fra kampagnen eller faste klummer med skæve vinkler på lokale kandidater. Til sammenligning har Urban Fyn 82 artikler om valgkamp, som altså næsten alle er produceret på landsplan.

Selvom gratisaviserne i min undersøgelse har mange artikler om valgkamp, er den lokale dækning fraværende, og når den er der, handler den helt markant om proces frem for politik.

Dermed er gratisaviserne i virkeligheden dybt uinteressante for politikere på lokal valgkampsturne. 


\section{De gratis ugeaviser dækker kun deres egne}

De gratis ugeaviser, som jeg har medtaget i min undersøgelse, dækker kun i meget begrænset omfang turneen og valgkampen generelt. De kun 27 lokalt producerede artikler i undersøgelsens 2 gange 14 undersøgte aviser har et tydeligt mønster i valget af citerede kilder (se tabel 5).

\section{Tabel 5}

Sådan citerer de gratis ugeaviser.

\begin{tabular}{lccc}
\hline & $\begin{array}{c}\text { Lokale } \\
\text { kandidater }\end{array}$ & $\begin{array}{c}\text { Andre } \\
\text { kandidater }\end{array}$ & $\begin{array}{c}\text { Ingen } \\
\text { kandidat }\end{array}$ \\
\hline Kilde i artikel & 15 & 3 & 9 \\
\hline
\end{tabular}

Samtlige citerede folketingskandidater er lokale, undtagen i de tre tilfælde, hvor partilederne optræder som kilder. En lokal kandidat viser sig her at være en kandidat, hvis opstillingskreds ligger i den gratis ugeavis' dækningsområde. Det er altså ikke nok at komme fra samme amt, kandidaten skal også komme fra den rigtige kreds. Alle de lokale artikler om valgkamp er endvidere historier med kun en kilde (typisk kandidaten), og både de to partiledere på turne (Pedersen, 2005a og 2005b) og de lokale kandidater får generelt mulighed for at uddybe deres synspunkter uden at blive modsagt.

Alle de 27 artikler handler enten om personer (18) eller proces (9). Den politikformulering, som foregår, sker tilsyneladende udelukkende i kraft af læserbreve, som jeg ikke behandler nærmere her. Problemet med de gratis ugeaviser er altså, at bussen rent fysisk skal parkeres i avisens dækningsområde, før den sender en journalist. Derfor kan man sætte et stort spørgsmålstegn ved, om indsatsen ikke er for stor i forhold til den enkelte gratis ugeavis' begrænsede oplag og dækningsområde.

\section{For kritisk, for fraværende eller for lokalt}

De undersøgte lokale medier behandler valgkamp meget forskelligt, men det er kun de gratis ugeaviser og TV 2-regioner som lever op til partiernes formodninger om ukritisk vinkling og nemmere adgang. De undersøgte dagblade og TV 2-regioner har næ- 
sten præcist samme fokus på proces og personer, som de landsdækkende medier har, og forskellene i valg af politiske emner er også små.

Undersøger man dækning af partiledernes konkrete turne, ses det for det første, at en stor del af artiklerne handler om de autonomes overfald i Svendborg. For det andet springer det i øjnene, at kun tre journalister har taget imod et af turneens vigtigste tilbud: Interview med kandidaten i bussen. De andre journalister laver reportager fra debatmøder med kandidaterne, hvor det jo ikke nødvendigvis er partierne, der sætter dagsordnen.

De lokale gratisaviser dækker næsten ikke valgkampen lokalt, og når de en sjælden gang gør det, beskæftiger de sig udelukkende med proces og skæve vinkler og ikke politik.

De regionale TV 2-stationer giver plads til partiernes turneer, og de dækker også indimellem mindre kritisk. Men de korte indslag har tendens til at drukne i den massive valgdækning, som stationerne allerede har, og partierne kunne formentlig have brugt deres „tildelte“ indslag på en måde, som krævede langt færre ressourcer.

De lokale ugeaviser synes således at være det medie, der bedst lever op til partiernes antagelser om en ukritisk vinklende presse, idet de udelukkende interviewer politikerne og kun har en kilde i hver artikel. Men de lokale ugeavisers dækning er samtidig klart lokalt orienteret. De interviewer kun kandidater, som har opstillingskreds i bladets dækningsområde, og min undersøgelse viser, at partilederne kun får omtale i de lokale ugeaviser, hvis de får tour-bussen til at stoppe i lokalavisernes begrænsede dækningsområde. Selv da er der ikke nogen garanti for dækning, da det ikke er alle de gratis ugeaviser, som overhovedet beskæftiger sig med valgkamp.

Partierne går ud fra, at partilederne får en mere lempelig behandling i de lokale medier med mere fokus på politik og en nemmere adgang til få deres politiske budskab igennem via en-kildes interviews. Men min undersøgelse viser, at det absolut er en sandhed med modifikationer.

Spørger man oveni de lokale journalister selv, om de er mindre kritiske, så svarer de ikke overraskende, at det er de ikke (Jønsson, 2004: 9). Mere interessant er det, at de siger, at de i de sidste år har 
oplevet en markant større interesse fra landsdækkende politikeres side (Jønsson, 2004: 8). Alene den oplevelse kan jo vække den kritiske sans hos enhver journalist!

De foregående siders undersøgelse har vist, at en række af de mediemæssige hypoteser bag partiernes lokale valgturneer samtidig hviler på et meget tyndt grundlag. Den faktiske adfærd hos de undersøgte medier afviger fra partiernes forventninger, og det må regnes for meget tvivlsomt, om turneerne har den mediemæssige gennemslagskraft, som partierne håber på.

\section{Er der andre muligheder end de lokale journalister?}

En anden antagelse bag partiledernes turne er, at de lokale journalister er den rigtige måde at nå de lokale medier på $i$ en valgkamp.

Ser man på tabel 6, er det allerede her tydeligt, at dette kun kan

\section{Tabel 6}

Her stammer avisernes valgstof fra. Procent

\begin{tabular}{lccc}
\hline & Lokale artikler & Bureau Stof & I alt \\
\hline Fyens Stiftstidende & 81 & 19 & 100 \\
\hline Viborg Stifts Folkeblad & 52 & 48 & 100 \\
\hline Skive Folkeblad & 29 & 71 & 100 \\
\hline Urban & 3 & 97 & 100 \\
\hline
\end{tabular}

\section{Tabel 7}

Andel artikler, hvor en politiker bliver citeret. Procent

\begin{tabular}{lccc}
\hline & Lokalt & Bureaustof & Landsplan \\
\hline Anders Fogh Rasmussen & 8 & 24 & 16 \\
\hline Venstrepolitikere i alt (med AFR) & 42 & 53 & 40 \\
\hline Mogens Lykketoft & 12 & 7 & 14 \\
\hline Socialdemokrater i alt (med ML) & 41 & 25 & 36 \\
\hline Andre politikere & 62 & 47 & 51 \\
\hline $\begin{array}{l}\text { Andel af alle artikler, } \\
\text { hvor en politiker bliver citeret }\end{array}$ & 62 & 54 & 50 \\
\hline
\end{tabular}


gælde for TV 2-regionerne og de gratis ugeaviser, der selv producerer alt stof. Især de mindre dagblade i min undersøgelse får en stor del af deres politiske nyheder fra landsdækkende nyhedsbureauer.

For at vurdere, hvor synlig en politiker er i medierne, kan man undersøge, hvor mange artikler han eller hun bliver citeret i. Den opgørelse har jeg lavet i tabel 7 .

Betegnelsen „Lokalt“ henviser til artikler produceret lokalt i de 5 undersøgte dagblade; „Bureaustof“ er den del af de kodede artikler om valgkamp, som ikke er produceret lokalt, mens „Landsplan“ refererer til de tal, jeg har trukket ud af datasættet til „Mediernes valgkamp“.

Disse tal viser med al tydelighed, at begge partiledere allerede er synlige i de lokale aviser. Det er dog samtidig også klart, at Anders Fogh Rasmussen har et klart forspring, hvad angår det lokale bureaustof.

Det ville være endog meget interessant at undersøge, hvorfor statsminister- og regeringseffekten slår så markant igennem i de lokale mediers bureaustof. Man kan gætte på, at det kan skyldes Ritzaus eller de lokale redaktionssekretærer prioritering.

\section{Venstre vinder klart på annoncerne}

En anden måde, hvorpå partierne og deres budskaber kan blive synlige i de lokale medier, er ved hjælp af annoncer. Undersøger man derfor antallet af annoncer i de undersøgte medier, bliver det tydeligt, at partierne indrykkede flere annoncer, end der var artikler om valgkampen. (408 annoncer mod 315 artikler)

Ser man på annoncesiderne, altså størrelsen af de enkelte annoncer, er Venstres forspring helt markant. Partiet har simpelt

\section{Tabel 8}

Annoncer i alle medier.

\begin{tabular}{lcc}
\hline & Antal & Annoncesider \\
\hline Venstre & 76 & 22,25 \\
\hline Socialdemokraterne & 44 & 5,25 \\
\hline Andre partier & 288 & 17,75 \\
\hline
\end{tabular}


hen ligeså mange annoncesider som alle andre partier til sammen. Denne voldsomme overvægt skyldes især, at Venstre har indrykket en række helsides annoncer i alle de undersøgte medier. Denne store mængde annoncer er selvfølgelig et udtryk for Venstres generelt store valgkampsbudget (Jønsson, 2004: 7) med alle de fordele, det medfører. I min sammenhæng er det især værd at bemærke, at dette store annoncebudget altså også betyder, at Venstre får en klar fordel i forhold til at nå læserne af de lokale medier.

\section{Andre veje i medierne}

Man kan nå de lokale dagblade og gratisaviser på andre måder end ved at sende partilederne på lokale turneer. Alle mine undersøgte dagblade, især gratisaviserne og de små lokale dagblade, fylder således deres spalter med bureaustof, som bliver produceret på landsplan.

Anders Fogh Rasmussen og Venstre har en fordel i bureaustoffet, formentlig i kraft af statsminister- og regeringseffekten, og i alle medier har Venstre en klar overvægt i annoncestoffet.

\section{Konklusion: Hvad så med turneerne?}

Denne undersøgelse viser klart, at de lokale medier ikke dækker partiledernes turneer, således som partierne forventer. De nye gratisaviser dækker nærmest slet ikke, de lokale ugeaviser kræver et besøg i deres dækningsområde for måske at sende en journalist, og de regionale TV 2-stationer har allerede sendefladen så proppet med valgkamp, at turneen kun giver et indslag pr. region.

Dagbladene dækker turneerne, men ikke så ukritisk og omfattende, som partierne forventer. En stor del af dagbladenes valgdækning kommer generelt fra Ritzau og andre nyhedsbureauer, og aviserne er i forvejen fyldte med annoncer. Alt sammen noget, som betyder, at partiernes udbytte af turneerne ikke bliver som forventet.

Det kan være, at turneerne rent faktisk virkede, da Venstre var de første og eneste, der turnerede, men i valgkamp 2005, som er basis for min undersøgelse, var en besøgende partileder ikke mere noget nyt. Turneerne var blevet mere omfattende, medier- 
ne havde rationaliseret og fusioneret og brugte mere bureaustof, og de lokale medier var ikke mere så villige til at dække turneerne - måske fordi de var blevet opmærksomme på, at de landsdækkende politikere regnede dem for mindre kritiske og nemmere at manipulere. Det er altid dumt at sige den slags højt.

Men hvad skal partierne så gøre? Og er det overhovedet så vigtigt at komme helt ud i landets yderste kroge?

I f.eks. USA og England, hvor valgsystemet betyder, at en stemme i Ohio eller Harwich er langt mere værd for partiet som helhed, end en stemme i New York eller Leeds, kan kandidaterne koncentrere deres kræfter i de valgkredse eller stater som er på vippen, og det giver langt bedre basis for kampagner målrettet imod de lokale medier. I Danmarks mere forholdstalsprægede valgsystem, er der godt nok lidt forfordeling til de tyndt befolkede områder, men det er nærmest umuligt præcist at udpege de områder, hvor det er særligt vigtigt at føre kampagne. Derfor kan det skyldes en fejlagtig følgeslutning fra amerikanske og engelske forhold, at vi har fået turneerne i deres nuværende form i Danmark (Jønsson, 2004: 3). For her i landet har partierne tværtimod brug for at nå bredt ud i alle områder frem for turneer, der ikke umiddelbart har nyhedsværdi for andre end de besøgte områder.

Der er derfor i virkeligheden kun én klar konsekvens for partierne at drage. Nemlig at de store centralt planlagte kampagner ikke kan gøre det alene. De bør for eksempel i langt højere grad udstyre de lokale kampagnecentre med redskaber til selv at tilrettelægge en kampagne målrettet mod de lokale medier. Som det er vist i denne artikel, er det nemlig umuligt for partierne at nå ud i alle afkroge af landet med partilederen. En centralt organiseret kampagne kan således godt slå igennem på landsplan $\mathrm{i}$ det redaktionelle stof og $i$ annoncer overalt i landet, hvis man har penge nok, men et parti er helt afhængig af lokale græsrødders kampagner, hvis det skal nå de lokale medier. Disse græsrødder kan man så selvfølgelig gøre en indsats for at professionalisere, strømligne og gennemorganisere, men meget af den lokale mediedækning afhænger i sidste ende af lokale initiativer. Det er også tydeligt, at i hvert fald Venstre er ved at lære den lektie (Venstre, 2005).

Spørgsmålet er så selvfølgelig, hvordan man fremover skal pro- 
movere partilederen? Det kan sagtens ske ved en eller anden form for lokal turne, for Christiansborg er et rigtigt kedeligt sted i en valgkamp, men så skal turneen i langt højere grad tilrettelægges, så de enkelte besøg også er relevante for f.eks. de landsdækkende nyhedsbureauer og ikke kun for de lokale dagblade, ugeaviser og TV-stationer.

Det betyder desværre for partierne, at de er tilbage ved startpositionen. De bliver nødt til at føre valgkamp med Christiansborg-pressen halsende efter sig.

\section{N O TER}

1. Artiklen bygger på en undersøgelse lavet i forbindelse med den afsluttende opgave på første del af den journalistiske kandidatgrad, cand. public. på SDU. Selve opgaven, som indeholder en lang række uddybende metodeforklaringer og mere indgående analyser af de enkelte medier samt selve datasættet er at finde på hjemmesiden www.serge.dk.

\section{REFEREN CER}

Andersen, Ole E. (2005). Nye kurver $i$ medialandskabet, Frederiksberg: Forlaget Markedsføring.

Bagger, Henning (2005). „Balancegang“, Urban Fyn, 27. januar, p. 1.

Bro, Peter m.fl. (2005). Mediernes Valgkamp - Et forsknings- og formidlingsprojekt om folketingsvalget $i$ 2005, København: MODINET.

Crewe, Ivor m.fl. (1998). Political communications: why Labour won the General Election of 1997, London: Frank Cass Publishers.

Elklit, Jørgen (2005). Danske Valgsystemer: Fordelingsmetoder, sporreregler, analyseredskaber, Århus: Institut for Statskundskab, Aarhus Universitet.

Jønsson, Rasmus m.fl. (2002). Professionel politisk kommunikation - et studie af 20 dages valgkamp, Akademisk Forlag A/S.

Jønsson, Rasmus (2003). Analyse af Socialdemokratiet: Voelgere giver spindoktorer let spin, Altinget.dk, 10 oktober 2003. Her brugt fra www.altinget.dk

Jønsson, Rasmus (2004). Socialdemokraterne og Venstres valgkamp på 
det regionale niveau, Ugebrevet A4, november 2004. Her brugt fra www.ugebreveta4.dk

Jønsson, Rasmus (2005). Valgsejr kræever postmoderne kommunikation, Altinget.dk, 22. maj 2005. Her brugt fra www.altinget.dk.

Hansen, Flemming m.fl. (2001a). Kommunikation, medieplanloegning og reklamestyring - Bind I: Metoder og modeller, Frederiksberg: Samfundslitteratur.

Hansen, Flemming m.fl. (2001b). Kommunikation, medieplanlagning og reklamestyring - Bind 2: Danske reklamemedia, Frederiksberg: Samfundslitteratur.

Kramhøft, Peter m.fl. (2001). „Journalistik med omtanke“, Århus: Ajour.

Markussen, Jesper (2005a). „S klar til at lave ny kommunalreform“, Viborg Stifts Folkeblad, 27. januar, p. 5.

Markussen, Jesper (2005b). „Fogh: 60.000 nye Jobs er realistisk“, Viborg Stifts Folkeblad, 31. januar, p. 3.

Moll, Jacob (2005). „På bagsædet af Linje A“, Fyens Stiftstidende, 30. januar, p. 3-4.

Pedersen, Frank (2005a) „Præsidentkandidaterne - Man skal være hårdhudet for at være med i politik“, Ugeavisen Odense, 2. februar, p. 30.

Pedersen, Frank (2005b) „Præsidentkandidaterne - Tanken om at være arbejdsløs skræmmer mig“, Ugeavisen Odense, 2. februar, p. 31.

Sepstrup, Preben (1999). Tilrettelaggelse af information, Århus: Forlaget Systime.

Socialdemokraterne (2005). Kampagneplan for Mogens Lykketoft, Frederiksberg, Socialdemokraternes partikontor.

Søllinge, Jette Drachmann (2005) Lokalpressen, Århus: Statsbiblioteket. Vith, Martin (2004). Venstres valgkampshåndbog, Holte: Venstres Landsorganisation.

Venstre (2005) „Dialog med Fogh - turneplan“, Holte: Venstres Landsorganisation. 